\section{Astronomy in Ships' Names}

A Number of Victory Ships recently launched from the slips of the California Shipbuilding Corporation at Wilmington, California, have been named after astronomers. Ship No. 125 of the corporation's wartime programme, the s.s. George E. Hale, was launched on January 19 last after only 27 days on the ways, and commemorates the inventor of the spectroheliograph and spectrohelioscope, founder of the Astrophysical Journal, and constructional genius mainly responsible for the design and erection of the world's largest refracting and reflecting telescopes at Yerkes and Mt. Wilson respectively. The s.s. Maria Mitchell, vessel No. 147, takes her name from the professor of astronomy at Vassar College, who discovered a comet and who was the first of her sex to be elected a member of the American Acaderny of Arts and Sciences. Ship No. 158, the s.s. Simon Newcomb, launched on March 26, is named after the famous superintendent of the American Nautical Almanac Office, who was commissioned professor of mathematics in the U.S. Navy by Abraham Lincoln and who did perhaps more than any other man to popularize astronomy in the United States.

\section{Tank-breeding Mosquitoes in Portsmouth}

Mr. John F. Marshall of the British Mosquito Control Institute at Hayling Island, Hants, has recently issued a pamphlet on the above subject. It deals with the incidence of mosquitoes in static water tanks in the Portsmouth City area. Viewed as a whole, it appears that size of tank is an important factor since the occurrence of mosquito breeding becomes more and more unlikely as capacities increase above the 10,000 gallon limit. Tanks of 5,000 gallons and 10,000 gallons capacities (the two smallest employed) provided one half of the total cases of the occurrence of mosquitoes in some stage of development. In none of these examples was the water heavily infested: in all the larger tanks or sumps mosquito larvæ, when present, were few and far between. The only species of mosquitoes found breeding in the water-containers were Culex pipiens and Anopheles maculipennis, although many other kinds prevail in the district. On each occasion upon which mosquito breeding was observed, notification was sent to the National Fire Service authorities, who forthwith sprayed the infested water with oil and/or cleared it of algal growths. The success of these operations was evidenced by the fact that with only one exception no tank was found to be mosquitoinfested more than once during the whole period considered (April-November).

\section{New Zealand Earthquakes}

ACCORDING to the seismolcgical bulletin just received from the Dominion Observatory, Wellington, New Zealand, nine large earthquakes were registered during February 1943 by the seismographs at Auckland, Arapuni, Christchurch, Tuai and Wellington (Dept. of Scientific and Industrial Research, New Zealand Seismological Report, Provisional Bulletin No. P-132, February 1943, Dominion Observatory, Wellington, N.Z.). Additionally during the month twenty-seven shocks were felt in New Zealand. Three of these attained intensity VI on the modified Mercalli scale. The first, on February 17 , occurred at $02 \mathrm{~h} .15 \cdot 2 \mathrm{~m}$. U.T. and was felt in the South Island, south of Buller and Canterbury, with intensity rather greater than VI. The second on February 17, at 13h. $52 \mathrm{~m}$. U.T., was again felt in the southern part of South Island with intensity VI. The third on February 25 at $13 \mathrm{~h}$. $33.5 \mathrm{~m}$. U.T. was felt from Taumarunui and Napier to Hokitika and Akaroa with intensity VI. One shock had intensity V. It was on February 20 at $01 \mathrm{~h}$. $48 \cdot 4 \mathrm{~m}$. U.T. and felt in the neighbourhood of Te Anau. Four shocks were felt with intensity IV and the remainder had lesser intensities.

\section{Occultation of Venus}

Mr. M. A. Elirson writes: "Permit me to correct and also to amplify the statement of planetary conjunctions given under 'The Night Sky in July' in Nature of June 26, p. 724. These are described both as conjunctions and as occultations: in fact it is only the conjunction of Venus which leads to an occultation visible in the British Isles. This daylight occultation (disappearance July 6 at $15 \mathrm{~h}$. $45 \mathrm{~m}$. for Greenwich) is of special interest by reason of the great brilliancy of the planet, which should render it an object easily visible to the unaided eye. The moon will be slightly west of the meridian at an altitude of about $50^{\circ}$. There follows, within half an hour, the occultation of $\alpha$ Leonis, a double event observable with a 2-in. telescope".

\section{Announcements}

IF circumstances permit, the Trustees of the Lady Tata Memorial Fund will make the following awards for research in blood diseases, with special reference to leukæmia, in the academic year beginning on October 1: Grants for research expenses: Dr. J. Furth (New York); Dr. P. A. Gorer (London); Dr. A, H. T. Robb-Smith (Oxford) ; Prof. L. Doljanski (Jerusalem). Part-time personal grant and grants for assistance and research expenses: Dr. W. Jacobson (Cambridge).

THE following appointments and promotions have recently been made in the Colonial Service: G. A. Walton to be medical entomologist, Sierra Leone; E. Lawrence, agricultural officer, Nyasaland, to be senior agricultural officer, Nyasaland; W. E. Calton, laboratory assistant, Tanganyika Territory, to be assistant Government analyst, Tanganyika Territory ; G. S. Brown, L. F. Higgens, L. Leslie Moore and W. S. Warne, agricultural assistants, Tanganyika Territory, to be senior agricultural assistants, Tanganyika Territory.

"Recoanition of Decay and Insect Damage in Timbers for Aircraft and other Purposes" is the title of a bulletin issued by the Department of Scientific and Industrial Research. It deals in the main with information for the use of timber inspectors and lists certain timbers in general use, with notes on their resistance to insect attack and decay. In its eighteen pages it deals with those defects and blemishes which occur most commonly in woods ordinarily used in the construction of aircraft and airscrews. The present shortage of timber has made it important to use it economically, and home-grown woods have been called on to make good the diminution of imports. The pamphlet is obtainable from H.M. Stationery Office or through any bookseller, price $6 d$. net. 